\section{Learning from Leibniz: Navigating the Twin Labyrinths of Academia and Practice}

Frank H. Weiner

Virginia Tech
"LEIBNIZ. In a certain sense you never see the sea, just as you never see the sky. The perception of the sea, with all its waves and reflections, is made up of thousands of miniscule, fleeting, imperceptible sensations. The wave that you see coming is made of movements of water that are so fine, tenuous and swift that you could never see them. This is why, although the sea is there right before your eyes, it is as if it remained eternally possible - it is the very image of possibility." (Giorgio Agamben, Pulcinella)

\section{INTRODUCTION: THE BEST OF ALL POSSIBLE ...}

This essay is prompted by a single phrase embedded in the call for papers - "...the best of all available knowledge..." It would be easy to overlook the significance of this brief extracted fragment by taking for granted we know and understand what is indeed the best in the context of the education of an architect. Within the overall framework of the conference such considerations could be seen as offering a relevant dialectical antithesis to the main thesis of the conference. It is important to consider how questions of the 'best' in relation to knowledge have come to be seen by some as being of lesser importance in our conversations about education. If we do not strive for what is the best then we may loose an overall sense of telos or purposiveness in our various endeavors. The best is the highest good (both in theory and practice). So the best is at least a double condition rather than a singular condition. In Aristotle's Eudemian Ethics there are no less than three philosophical meanings of the word "best". First there is best as the Idea of the good (here Idea in a Platonic sense and the good are synonymous), secondly the best as the common good and thirdly the best in a practical sense. ${ }^{2}$ There is then a noble best and a practical best.

The viability of the conference theme on "The Practice of Teaching and the Teaching of Practice: The Teacher's Hunch" may actually rely upon establishing a foundation for determining what the best of all available knowledge consists of towards our common pursuits. Here one might propose the word 'available' be replaced by the word 'possible' so the fragment would now read - the best of all possible knowledge. The distinction between availability and possibility although seemingly minor becomes a crucial one. Availability has to do with use and acquisition in the sense that something or someone is either available or is not available. The notion of availability lacks the gravitas of possibility that can lead to actuality. With the idea of possibility emerges the transcendental question of the freedom for good and evil adjudicated under a form of divine justice. Invoking possibility over availability is an acknowledgment of the perennial importance of the ancient Aristotelian dyad of potency/act in the deeper background of our theories and practices. In a world of crass availabilities, "need is so many bananas. ${ }^{3}$ In what follows the word "knowledge" is understood in Aristotelian sense of the fourfold of causation giving us the possibility to bring forth what we know, what Heidegger poeticized as modes of occasioning - the material, formal, efficient and final causes. ${ }^{4}$

A series of questions now arise. In a world seemingly overtaken by a kind of identity-based relativism is it still possible and worthy to 
strive for what is best? The idea of the best may strike some readers as an outdated authoritative quest for establishing an impossible universal against the exigencies of the individual but clearly we are in need of some general concepts to guide our common endeavors in teaching and practice. Could this simple fragment from the call for papers potentially assist us in assessing our current situation as educators and practitioners of architecture? What would it mean to bring the best of all possible knowledge to the setting of an academic design studio and the education of an architect in general? Can we know what is the best outside of an ontotheological framework? ${ }^{5}$ Here one veers with caution and some trepidation into questions of faith in a post-secular age.

\section{TOWARDS A THEODICY OF THE EDUCATION OF AN ARCHITECT}

Almost immediately when thinking of the idea of the best the thought of Leibniz's Theodicy comes to mind and his idea that despite of (an even because of) the existence of evil this is indeed the best of all possible worlds, as God would not have done otherwise. ${ }^{6}$ To better understand the general intention of any theodicy Kant, a strong critic of theodicy, clearly articulates what theodicy is. He writes theodicy is "...the defense of the highest wisdom of the creator against the charge which reason brings against it for whatever is counterpurposive in the world." An example of something counterpurposive is the existence of evil. Why would the best permit evil? The problem of the existence of evil has vexed the most brilliant philosophers for centuries. It is however important in this particular discussion.

Critics of the Theodicy such as Voltaire responded with disdain, especially in light of the great Lisbon Earthquake of 1755 arguing if this is the best of all possible worlds how does one account for the actual existence of evil, injustice and calamity under the so-called justice of God? Other critics such as Immanuel Kant, like a lawyer prosecuting a case in the "court of philosophy", made a point-by-point refutation of any form of theodicy. For Kant all theodicy (literally meaning the justice of God) including Leibniz's was a presumptuous "miscarriage" of the architectonic limits of knowledge and reason claiming to make what is inscrutable to us (God's way) be an open book to be read by mere mortals. ${ }^{8}$ While accepting the powerful critique of the idea of theodicy undertaken by Kant and others it is the intent of this essay to remain open to the 'optimistic' and 'extravagant' possibilities articulated by Leibniz. For in the end we must believe in what we teach and how we practice. Confusing knowledge with belief can be a fatal error especially in education. You must know something to teach but more importantly one must believe in something. In a non-theological sense we do not teach what we know but what we believe. ${ }^{9}$ These considerations may in fact have a real bearing on how we frame our questions as educators in and practitioners of architecture in the particular moment we are in. The ideas of practice and research are now forming a new coalition within the academy that may in fact change the face of academia in ways not foreseen. All things practice-based have supplanted scholarship formerly grounded in the history of ideas. ${ }^{10}$

\section{FREEDOM AND RESPONSIBILITY}

"Freedom belongs not to the empirical but solely to the intelligible character The operari of a given human being is determined necessarily from outside by motives, from inside by his character: therefore everything he does happens necessarily. But in his esse, that is where freedom resides. He could have been another: and in what he is resides blame and merit."

(Arthur Schopenhauer)

Giorgio Agamben in paraphrasing Schopenhauer writes that we are responsible not for what we do but what we are. ${ }^{11}$ What we are provides sufficiency for what we do. After Leibniz Schelling's treatise on the essence of human freedom becomes a crucial piece of the puzzle. ${ }^{12}$ For Schelling freedom was the possibility for good and evil. ${ }^{13}$ The inclusion of evil in relation to freedom may strike some readers as surprising however it allows for a fuller account of the nature of our common essence. Schelling saw a dark ground at the heart of the essence of freedom - what he termed a non-ground. ${ }^{14}$ He wanted to challenge the generally accepted notion of good and evil as mere oppositions. The proclivity towards the non-ground was the discovery of an abyss. The turn towards the abyssal leads to Heidegger's course on Schelling's treatise..$^{15}$ One is now poised somewhere between Kantian morality and Heideggerian ontology. On the one hand there is the architectonics of an imperative of moral duty in support of the good life and on the other the mystical search for a dark ground emanating from the question of Being. Also important in this context is the work of Heidegger's brilliant students such as Werner Marx and Hans Jonas whom along with Arendt detected a significant void in Heidegger's refusal to incorporate questions of ethics into his philosophy. ${ }^{16}$

In view of such broader considerations, what is our responsibility as academics and architects towards offering the best of all possible educations in architecture? The notion of an ethics of "extended responsibility" as articulated by Hans Jonas appears to be relevant to our situation. By invoking the idea of responsibility our timeless theoretical speculations can be measured by the impact they may have given the possibility of their realization in time. In other words we take responsibility (as a parent does for a child) for our ideas vis-à-vis others and the concrete actions stemming from these ideas.

Central to the idea of theodicy is the idea of human freedom especially as it involves the status of the willing individual harboring certain inclinations towards good and evil. It is striking in many of our recent attempts to change the nature of what and how we teach architecture the ideas of freedom and free will are overlooked. As has been said freedom is the capacity or faculty that gives us all the others. ${ }^{17}$ Freedom is the possibility of good and evil. In the realm of freedom both good and evil are possible. The best of all possible worlds depends on the possibility of the mystery play of freedom. Freedom understood transcendentally makes knowledge possible.

Is there a model for the education of an architect offering the requisite educational freedom and responsibility for both faculty and students to thrive? It may be too late for experiments like Summerhill but this educational experiment should not be disregarded relative to the importance of freedom in an educational setting. ${ }^{18}$ There were rules 
at Summerhill without which the place would have tended towards total chaos. What would be the nature of such freedom in a school of architecture today and how would this play out in reality? A school without freedom is not a school. In order to take up such questions recourse to both the horizons of theory and practice are necessary. Theory allows us to generalize and practice to specify. What are the general conditions for the "best" education in architecture and what are the specifications? The general conditions would be the structure and the curriculum would be the organization for such as education. Are we able to adequately relate our generality to our specificity?

\section{THEORY AND PRACTICE}

Reflections on the idea of theory and practice are relevant to the main theme of the conference seeking to bridge academia and practice. One could posit a simple analogy such that teaching is to theory as the profession of architecture is to practice. In this respect theory and practice are the twin ground(s) of our co-related activities. One of the first philosophers to take up the question of 'theory and practice' was Immanuel Kant in his essay "On the Common Saying: "This May be True in Theory, but It Does Not Apply in Practice". ${ }^{19}$ As the title suggests such a widely held belief, challenged by Kant, serves to totally neutralize the self-efficacy of theory leaving practice exposed on its own shoal of the empirical. As to the conjoining of 'theory and practice' Kant writes; "It is obvious no matter how complete a theory may be, a middle term is required between theory and practice, providing a link or transition from one to the other." ${ }^{20} \mathrm{He}$ adds; "For a concept of the understanding, which contains the general rule [theory], must be supplemented by an act of judgment whereby the practitioner distinguishes instances where the rule applies from those where it does not." 21

How did it come to pass we somewhat lazily conjoin the terms theory and practice? What does the middle term mean in this case? Slavoj Žižek has attempted to see the middle term "and" as a conceptual category bridging ideology and science. In his view the ambiguity in the use of the word 'and' tautologically combines the same content in two modalities. ${ }^{22}$ Stated another way the "and" is the common part of both theory and practice. Once could contend the taking for granted of the union of the two has done more harm than good. One could lay blame on the Marxists shift from ancient practice grounded by phrónesis or practical wisdom to the idea of modern praxis but this accusation would not be quite fair. In Marx and others theory became a critique of political, economic social conditions. ${ }^{23}$ The question of theory and practice was redirected towards material conditions of our existence rather than the life of the mind. The ancient disinterest of theory was of no interest to Marx and his generation. In Marx there is a deliberate turn where 'theory and practice' became ideological and 'critical' in nature and breaks from its classical moorings. In either a materialist or idealist view we appear to be on shaky ground by insisting on thinking of the assumed totality of 'theory and practice' coloring most of our thinking on teaching and practice. We know more about theory and practice considered separately than we do in the combination of the two through the little word "and". ${ }^{24}$

\section{TOWARDS A PHILOSOPHY OF PRACTICAL PRACTICE IN ARCHITECTURE AND ARCHITECTURAL EDUCATION}

There has been notable increase globally in many forms of 'practice-based research' activities in schools of architecture. This is part of a larger desire to bring academic legitimacy to those teaching architecture in the academy and to contribute to communities the academy serves. Community service or outreach is then charged to simultaneously address research innovation. This may be asking too much from faculty and students. It is not enough to serve well one must also innovate while serving. ${ }^{25}$ Given these evident sea changes the relationship of the ideas of theory and practice are especially in need of examination and perhaps reformulation. The notion of sea change is invoked in the Shakespearian sense of a metamorphosis rather than its more limited prosaic meaning in the world of business or institutions. ${ }^{26}$ In a remarkable reversal our practice may have metamorphosed unwittingly into our poeisis.

Practice is now studied and permeated for its own sake as a kind of practice of practice. Practice itself is valued over what practice produces - a building. Poetics then becomes of lesser importance and subsumed by notions of current social viability and trends. What becomes of poetics overrun by the technologies of practice? It is becoming common to study a firm as if it were a society. Firms now receive awards such as the AIA firm of the year in the US. Such awards are impressive and noteworthy however the judgment as to the quality of the built work becomes secondary. These considerations dramatically challenge the ancient distinction based on the fundamental bifurcation of action to that which is made (poeisis) and that which is decided (praxis). Given the above considerations is even more important to better understand the ancient composite we somewhat lazily conjoin as 'theory and practice'.

Hans-Georg Gadamer's idea of "practical philosophy" places the propositional (theory) and the decisive (practice) side by side as intertwined correlates. The doctor cures, the lawyer defends and the architect acts through making. There are no claims to universality in these practicing actions making the teaching of these professions complex. However the legitimacy of those practicing medicine, law and architecture is based upon an idea of practical wisdom known as phrónesis. The questions becomes how does one teach practical wisdom or reasonableness? This wisdom leads to practical decisions pertaining to what is good in certain situations. These decisions may be otherwise but still occur within an idea of reason. There is a tendency to believe given this lack of universality theory holds a superior position to practice. For Gadamer both theory and practice are supreme forms of reason. Practice is a form of practical reason about what is good or what he calls " the right thing to do". ${ }^{27}$ This is very different from the search for immutability theory seeks. The "bliss of theory' grazes up against the hard edges of practice. Theory and practice are not oppositions but rather in Gadamer's 
sense exist as contrasts within knowledge. The aim of practical philosophy is practice. Gadamer writes; "... in the sphere of practice the conclusion is not a proposition (Schluss) but a decision (Entschluss)." 28 The realm of practice in architecture is a realm of extended responsibility where measured decisions have consequences upon others and generations to come.

\section{LEARNING FROM LEIBNIZ: TOWARDS THE BEST OF ALL POSSIBLE STUDIOS?}

In the preface to Leibniz's Theodicy he distinguishes between what he calls two great labyrinths where reason loses its sway - one is practical and the other theoretical or speculative. The Theodicy is a guide to navigating these labyrinths. Under the rubric of the practical is the question of how evil necessarily arises in the lives of human beings. The question of continuity and how indivisibles arise falls under the theoretical. The practical question gives rise to theodicy (the justice of God) and the theoretical to his theory of indivisible monads. The Theodicy famously states this world is 'the best among all possible worlds' since God would have not done otherwise. The argument is theological and faith grounds its rational necessity.

Leibniz acknowledges evil does indeed exist but this alone is no reason to lose faith in the overwhelming goodness of the created world in which evil makes its exceptional appearance. In the constant face of the provisional, contingent and the flaring up of evil one of the only recourses available is searching for a necessary rational order amidst prevailing conditions. This was the core of Leibniz's Theodicy and one that could inform our notions of an academic studio today.

A series of questions arise viewing the state of our academic design studios today through and beyond the supra-rational lens offered by Leibniz. Should our studios respond to surrounding contingencies/ circumstances or should they seek harbor in search of more stable incorruptible ground? Should the best of all possible studios be a rational studio (if this were at all possible)? Should the pursuit of the best (either for a teacher or student) be the purpose of a studio? Can the idea of theodicy (meaning literally the justice of God) be analogous to the construction of a just and jussive pedagogy of the studio? Lastly, what is the place of memory, desire, imagination and phantasm in our studios?

The jussive mood would suggest both teacher and student have desires, wishes, obligations, and responsibilities to respond poetically to the call of architecture. I would term this an inner authority from both the individual and architecture itself. Here one seeks a grounding of the best bracketed from theism - a kind of secular theodicy of the individual. The best would have two modes - an overarching Platonic metaphysical best and a down to earth Aristotelian practical best. For something to be best it must have virtue in a world and in a particular situation. The best of all possible studios would be framed by questions about the possibility of practicing perfection realizing full well imperfect things will result. Peter Sloterdijk reminds us there is a vestige of the summum bonum (highest good) within us allowing us to practice fateful imperfection. ${ }^{29}$ Without the trace of the highest good (the best) our practice is without fate or destiny. It lacks a greater purposiveness. This purposiveness requires a notion of justice whether of divine or early origins. The Theodicy of Leibniz reminds us that the elimination of idea of justice from our considerations becomes a fatal error. To paraphrase Aristotle, justice is the proportional practice of virtue. ${ }^{30}$ As a corollary one might add practice without virtue is not practice. ${ }^{31}$

\section{RE-ATTUNING THE ACADEMIC STUDIO: QUESTIONING THE PRIMACY OF THE PROJECT}

As studios are tending towards projects of increasing socio-political relevance we move into a circumstance of contingency determined in large part by the news cycle. The overwhelming demand for offering such projects can overtake and negate the possibility for seeking poetic ideas of greater duration in architecture. Why has the ballistic notion of project gained such a position of primacy in the education of an architect? If an object stands over and against us a project is cast away from us. In neither case are we dealing with a things standing presence before us. ${ }^{32}$ Much like random projectiles projects are objects willfully projected into the future but never things in the here and now. ${ }^{33}$

As Habermas has stated the modern project is by nature 'incomplete'. ${ }^{34}$ This difficulty at the heart of modernity suspends the possibility of entelechy indefinitely and is a form of infinite regress. The education of an architecture must include the modern but not at the expense of the ancient. This suggests the employment of modern means side-by-side with an ancient ethos. ${ }^{35}$ The dialectic between incompletion and completion is at the heart of the education of the architect and of architecture. This is the challenge all projects present. The virtue of projects is they allows for mistakes to occur. ${ }^{36}$ The adjustment to mistakes projects the project forward while the mistakes themselves hold the project from moving forward. This holding is of paramount importance. This is particularly true when groups of students work on design-build projects at any scale. The setbacks that occur during construction are valuable to their practical moral education. This is the 'back and forth' fateful imperfection invoked by Sloterdijk.

There appears to be little alternative outside of proceeding on a project centric basis whether on paper or in the field. The project itself is never and will never be enough. The projective focus can overshadow the importance of the free and ethically autonomous development of a student. There is the project we as faculty give and there is the 'project' of education - the formation of the character of an individual - what some have termed paideai. ${ }^{37}$ In an office projects perhaps have a different status. However there is still the need for a greater motive beyond single projects that ties many projects together making them into a singular project over time or what one could better term a body of work. There is a rich dialectic between a body of knowledge and a body of work. ${ }^{38}$ The work of Aldo Rossi may serve as one such example of a coherent line of thought carried across multiple projects over many years of practice. Projects are necessary but may not be sufficient either for the education of an architect or the practice of architecture. The best of all possible knowledge would be a search for this sufficiency. Over dependence on projects can 
distract us from establishing this sufficiency. One is lead to the following rhetorical conclusion - less projects more sufficiency.

The status of projects notwithstanding the world of the studio should guide students to become more attuned to the importance of practical wisdom grounding acts of poeisis. This effort strives for the dialectic of theoretical propositions and the wisdom inherent in refining practical decisions. We need to think both under the 'aspect of eternity' and in the temporal present. This endeavor requires modes and moods of en-souled action to find one's way into the best possible twin overlapping labyrinths of the education of an architect and the practice of architecture. In the words of Goethe -

"Let us enter, calm of mind.

Confident that we shall find

Somewhere, certainly, the best." 39

\section{Notes}

1. The full call for papers for the 2019 ACSA/EAAE Teachers Conference, Antwerp Belgium can be accessed at, http://www.acsa.org.

2. Aristotle, Eudemian Ethics, The Works of Aristotle Translated into English, ed. W.D. Ross, Vol. IX, (Oxford: Oxford University Press, 1915).

3. This ironic statement is from a lecture delivered by Louis Kahn at the School of Architecture at Tulane University. A print version of this lecture was published as, ARCHITECTURE: The John William Lawrence Memorial lectures, The Tulane University School of Architecture, Louis Isadore Kahn, 1972.

4. The reformulation of Aristotle's four causes as poetic modes of occasioning can be found in Martin Heidegger's essay "On the Question Concerning Technology, David Ferrell Krell, ed. and trans., Martin Heidegger: Basic Writings (New York: Harper and Row, 1977), pp. 287-317.

5. The neologism "ontotheology" juxtaposes the seemingly incompatible study of ontology with questions of theology. The term was first introduced by Kant and later developed in a much different manner by Heidegger. In the context of the education of an architect or the practice of architecture it may strike readers as an obscure and irrelevant idea. However the dismissal of the search for foundations and grounds for our common endeavors appears to be a significant omission greatly reducing the opportunities to find what is sufficient beyond addressing mere practical necessity. For more extensive background on the idea of ontotheology, see, lain D. Thomson, Heidegger on Ontotheology: Technology and the Politics of Education (Cambridge: Cambridge University Press, 2005).

6. The full title of the original work was written in French, Essai de Théodicée sur la bonté de Dieu, la liberté de l'homme et l'origine du mal. The work is commonly referred to in English by the short title of Theodicy. For a translation of this work in English see, G. W. Leibniz, Theodicy: Essays on the Goodness of God the Freedom of Man and the Origin of Evil, trans. E. M. Huggard (Chicago: Open Court, 1985). The original was published in 1710.

7. Immanuel Kant, "On the miscarriage of all philosophical trials in theodicy" in, Immanuel Kant: Religion and Rational Theology, ed. and trans. Allen Wood (Cambridge: Cambridge University Press, 1996), PP. 24.

8. Immanuel Kant, "On the miscarriage of all philosophical trials in theodicy".

9. Conversation with the late Professor Olivio Ferrari, undated. This seemingly cryptic statement is of considerable importance with the respect to a teacher following their intuition. Students can immediately recognize when a teacher is mechanically conveying knowledge rather than sharing what they believe about what they know.

10. The question of what constitutes legitimate research or scholarship in the academic discipline of architecture remains an important ongoing conversation. In architecture the notion of practice has once again come to the forefront. The fit of professional programs such as architecture within the overall framework of a University has never been a settled manner. In any case one can observe a clear movement away from pure research towards applied research in many fields particularly in architecture. This distinctions seem to more readily apply to the sciences than architecture per se. A reasonable and rich taxonomy for academic research and scholarship has yet to be developed if indeed one exists.

11. Giorgio Agamben, Pulcinella: or Entertainment for Kids in Four Scenes, trans. Kevin Attell (London: Seagull Books, 2018), pp. 114. It is the contention of this paper that what we do relates to practice as what we are relates to theory.

12. F.W. J. Schelling, Philosophical Investigations into the Essence of Human Freedom, trans. Jeff Love and Johannes Schmidt (Albany: State University of New York Press: 2006). The original was published in 1809.

13. F.W. J. Schelling, pp. 23.

14. F.W. J. Schelling, pp.69-70.

15. Martin Heidegger, Schelling's Treatise on the Essence of Human Freedom, trans. Joan Stambaugh (Athens: Ohio University Press, 1985).

16. Hannah Arendt's philosophical differences with Heidegger are well documented. In this respect the work of Hans Jonas and Max Werner are also noteworthy. See, Hans Jonas, The Imperative of Responsibility: In Search of and Ethics for the Technological Age (1984) and Werner Marx, Is there a Measure on Earth?: Foundations for a Nonmetaphysical Ethics (1987).

17. Martin Heidegger, 1985.

18. A. S. Neill, Summerhill: A Radical Approach to Child Rearing (New York City: Hart Publishing Company, 1960).

19. Immanuel Kant, "On the Common Saying: 'This May be True in Theory, but it does not Apply in Practice'", Kant: Political Writings, ed. Hans Reiss, trans. H. B. Nesbet (Cambridge: Cambridge University Press, 1970), pp.61-92. 
20. Immanuel Kant, "On the Common Saying: 'This May be True in Theory, but it does not Apply in Practice'”, Kant: Political Writings, pp.61.

21. Immanuel Kant, "On the Common Saying: 'This May be True in Theory, but it does not Apply in Practice'", Kant: Political Writings, pp.61.

22. Slavoj Žižek, The Invisible Remainder: On Schelling and Related Matters (London: Verso, 2007), pp. 104.

23. For a general account of the question of 'theory and practice' from a neo-Marxist point of view see, Jürgen Habermas, Theory and Practice, trans. John Vietel (Boston: Beacon Press, 1973).

24. For a discussion of the little word "and" from a more Hegelian perspective see, Slavoj Žižek. The Invisible Remainder: On Schelling and Related Matters (London: Verso, 2007), pp. 103-106.

25. My own institution Virginia Tech has as its motto the Latin phrase Ut Prosim. This roughly translates to That I May Serve.

26. The term sea change or sea-change is used in Shakespeare's Tempest (see the verse passage known as "Ariel's Song"). It is in this sense of a substantial transformation that the word has relevance rather than as a catch phrase often used in business or corporate settings.

27. Hans-Georg Gadamer, "The Idea of Practical Philosophy", Ch. VI, The Idea of the Good in Platonic and Aristotelian Philosophy, trans. P. Christopher Smith (New Haven: Yale University Press, 1986), pp. 160. See also, Hans-Georg Gadamer, "Hermeneutics as Theoretical and Practical Task", Ch. 10, The Gadamer Reader: A Bouquet of the Later Writings, trans. Richard E. Palmer (Evanston: Northwestern University Press), pp.247-265.

28. Hans-Georg Gadamer, "The Idea of Practical Philosophy", Ch. VI, The Idea of the Good in Platonic and Aristotelian Philosophy, trans. P. Christopher Smith (New Haven: Yale University Press, 1986), pp. 165.

29. Peter Sloterdijk, You Must Change Your Life: On Anthropotechnics, trans. Wieland Hoban (Cambridge: Polity Press, 2013), pp. 251. This book also presents important and challenging ideas about our practicing life.

30. Aristotle, Ethica Nichomachea, The Works of Aristotle Translated into English, ed. W.D. Ross, Vol. IX, Book V (Oxford: Oxford University Press, 1915).

31. For the idea of virtue I would direct the reader to Book VI of the Ethica Nichomacheacited in note 30 above.

32. For the philosophical distinction between a scientific object and a poetic thing see, Martin Heidegger, "The Thing", Poetry, Language, Thought, trans. Albert Hofstadter (New York: Harper and Row, 1971), pp. 163-186. For the idea of the dominance of the technological object over the poetical thing see Heidegger's essay "On the Question Concerning Technology" cited in note 4 above.

33. For a deeper understanding of the idea of "project" and the related idea of "projection" see, Martin Heidegger, Contributions to Philosophy (Of The Event), trans. Richard Rojcewicz and Daniel Vallega-Neu (Bloomington: Indiana University Press, 2012), pp.349-359. The original text in German was written between 1936-38 and published posthumously in 1989. For Heidegger the project of projection is meaningful only in relation to the temporality and historical throwness of Daesin or beyng. Projection tied to the traditional study of being (ontology) is caught up in regimes of representation and the human being as a Kantian subjectum. Projects in this sense lack the projection of being and are mere objects.

34. Jürgen Habermas first presented this idea in his acceptance speech as the recipient of the Theodore -W.-Adorno Prize in 1980. This was published as an essay under the title, " Modernity - An Incomplete Project", The Anti-Aesthetic: Essays on Postmodern Culture, ed. Hal Foster (Port Townsend: Bay Press, 1983), pp. 3-15. For an enlightening study on the unconsidered pathologies of modernism see, Louis A. Sass, Madness and Modernism: Insanity in the Light of Modern Art, Literature and Thought (New York: Basic Books, 1992).

35. This idea was suggested to me via an E-Mail correspondence by Emeritus Prof. Salahuddin Choudhury, August 2019 (Virginia Tech). Carlo Scarpa was an exemplar of this rich dialectic.

36. Conversation with Prof. Steven Thompson July 2019. The idea of undertaking projects where one can and often must make mistakes and overcome mistakes is in fact a virtue. This is true whether one is designing (or building) a small garden shed or an entire city.

37. See, Werner Jaeger, Paideia: The Ideals of Greek Culture, 3 vols. (Oxford: Oxford University Press, 1965). The current emphasis on projects can overwhelm the importance of paideia.

38. The notion of an undisturbed body of knowledge or body of work, and by analogy a body itself has been intelligently challenged by the notion of disfiguring. See, Mark Taylor, Disfiguring: Art, Architecture and Religion (Chicago: University of Chicago Press, 1992).

39. Goethe, Faust: Parts One and Two, trans. George Madison Priest, Great Books of the Western World, Vol. 47. Goethe (Chicago: Encyclopedia Britannica, Inc., 1952), pp. 134. 